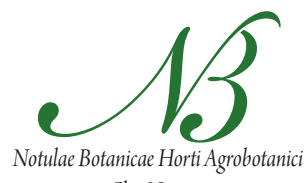

\title{
Sustainable Management of Nardus stricta L. Grasslands in Romania's Carpathians
}

\author{
Vasile VINTU*, Costel SAMUIL, Culita SIRBU, Constantin \\ Iulian POPOVICI, Mihai STAVARACHE \\ University of Agricultural Sciences and Veterinary Medicine, 3 Aleea M. Sadoveanu, \\ 700490, Iasi,Romania; vvintu@uaiasi.ro (*correspondingauthor)
}

\begin{abstract}
The grassland area of Romania covers over 4.8 million hectares, of which more than a half are located in upland areas. In the present research it has been studied the influence of organic fertilization on the productivity, vegetal canopy and fodder quality of the intramontane Depression of Vatra Dornei, from the North-Eastern Romanian Carpathians, at rates of 20-50 Mg ha ${ }^{-1}$, applied either on a yearly basis, or every two years. The purpose of this study is to underline the dynamics of productivity and phytocenosis biodiversity, due to the application of some practical, technical measures meant to improve the production and fodder quality of Nardus stricta $\mathrm{L}$. permanent grasslands, with minimal effects on the environment. The organic fertilizer rates triggered changes in the canopy structure by reducing the percentage of Nardus stricta L species, from 70\% to 14-31\%, and increasing the percentage of legumes, as well as the productivity and fodder quality 5-30\%, respectively.
\end{abstract}

Keywords: biodiversity, fertilization, fodder quality, grassland, productivity

\section{Introduction}

In Romania, the grassland area, dominated by Nardus stricta L., covers 200,000 hectares.

Meadow degradation is determined by changes that take place in plant living conditions and in the structure of vegetation. For a long-term period no elementary management measures were applied on permanent meadows in Romania, estimating that they could get efficient yields without technological inputs. The organic fertilization has a special significance for permanent meadows if their soils show some unfavourable chemical characteristics. The investigations carried out until today have demonstrated the positive effects of reasonably applied manure on grasslands.

Within this context, the main aim of the present study was to improve the productivity of natural grasslands by finding economically efficient solutions that respect their sustainable use and the conservation of biodiversity (Basnou et al., 2009, Bullock et al., 2007, Klavina et al., 2001, Tilman et al., 1996). An important factor in getting a high quality animal production is the quality of fodder, which is determined by its chemical composition. On the other hand, the productivity and fodder quality are influenced by the floristic composition, morphological characteristics of plants, grassland management, vegetation stage at harvest and level of fertilization (Aarssen, 1997; Belanger et al., 2008; Bullock et al., 2007; Dodd et al., 2004; Duru et al., 2010; Gaisler et al., 2004; Hejcman et al., 2010; Mag- yar et al., 2008; Potsch, 1998; Sivicek et al., 2011; Tilman et al., 1996; Vintu et al., 2008; 2011).

\section{Materials and methods}

To accomplish the objectives of these studies it have been conducted a monofactorial experiment in the Cosna region, in four repetitions blocks with 20-sq. meter randomized plots on Nardus stricta L. grasslands, situated at an altitude of $840 \mathrm{~m}$, on lithic dystrudepts with $1.36 \mathrm{mg} / 100$ g soil $\mathrm{P}_{\mathrm{AL}}$ and $38.1 \mathrm{mg} / 100 \mathrm{~g}$ soil $\mathrm{K}_{\mathrm{AL}}$ (Bakker et al., 2002, Janssens et al., 1998).

The fertilization variants were: $\mathrm{V}_{1}$-Unfertilized control; $\mathrm{V}_{2}-20 \mathrm{Mg} \mathrm{ha}^{-1}$, every year; $\mathrm{V}_{3}-30 \mathrm{Mg} \mathrm{ha}^{-1}$, every year; $\mathrm{V}_{4}-40 \mathrm{Mg} \mathrm{ha}^{-1}$, every year; $\mathrm{V}_{5}-50 \mathrm{Mg} \mathrm{ha}^{-1}$, every year; $\mathrm{V}_{6}$ $-20 \mathrm{Mg} \mathrm{ha}^{-1}$, every 2 years; $\mathrm{V}_{7}-30 \mathrm{Mg} \mathrm{ha}^{-1}$, every 2 year; $\mathrm{V}_{8}-$ $40 \mathrm{Mg} \mathrm{ha}^{-1}$, every 2 years; $\mathrm{V}_{9}-50 \mathrm{Mg} \mathrm{ha}^{-1}$, every 2 years.

The forage obtained from these grasslands is mainly used to feed dairy cows. The influence of manure has been analysed, and applied each year or every two years at rates of $20-50 \mathrm{Mg} \mathrm{ha}^{-1}$ (Tab. 1). The manure with a content of $0.42 \%$ total $\mathrm{N}, 0.19 \% \mathrm{P}_{2} \mathrm{O}_{5}$ and $0.27 \% \mathrm{~K}_{2} \mathrm{O}$ was applied by hand, early in spring, at the beginning of grass growth. The Kjeldahl method was used for the determination of crude protein, the Weende method for the determination of crude fiber, the photometrical method for the determination of total phosphorus, ash was determined by ignition, whereas the nitrogen nutrition index (NNI) was determined by the method developed by Lemaire et al. 
Tab. 1. Influence of organic fertilization on the yield of Nardus stricta grasslands from the Carpathian Mountains of Romania $\left(\mathrm{Mg} \mathrm{ha}^{-1} \mathrm{DM}\right)$

\begin{tabular}{ccccc}
\hline \multirow{2}{*}{ Manure rate } & 2009 & 2010 & \multicolumn{2}{c}{$\begin{array}{c}\text { Average of } \\
2009-2010\end{array}$} \\
\cline { 2 - 5 } & $\mathrm{Mg} \mathrm{ha}^{-1}$ & $\mathrm{Mg} \mathrm{ha}^{-1}$ & $\mathrm{Mg} \mathrm{ha}^{-1}$ & $\%$ \\
\hline Unfertilized control & 1.25 & 2.30 & 1.77 & 100 \\
$20 \mathrm{Mg} \mathrm{ha}^{-1}$, every year & $2.55^{*}$ & 2.40 & 2.48 & 140 \\
\hline $30 \mathrm{Mg} \mathrm{ha}^{-1}$, every year & $2.34^{*}$ & $4.23^{* *}$ & $3.29^{* *}$ & 186 \\
\hline $0 \mathrm{Mg} \mathrm{ha}^{-1}$, every year & $3.59^{* * *}$ & $4.74^{* * *}$ & $4.17^{* * *}$ & 236 \\
\hline $50 \mathrm{Mg} \mathrm{ha}^{-1}$, every year & $4.73^{* * *}$ & $6.32^{* * *}$ & $5.53^{* * *}$ & 312 \\
$20 \mathrm{Mg} \mathrm{ha}^{-1}$, every 2 years & 2.28 & 2.92 & 2.60 & 147 \\
\hline $30 \mathrm{Mg} \mathrm{ha}^{-1}$, every 2 years & $2.59^{*}$ & 3.13 & $2.86^{*}$ & 162 \\
\hline $40 \mathrm{Mg} \mathrm{ha}^{-1}$, every 2 years & 1.78 & $4.14^{* *}$ & $2.96^{*}$ & 167 \\
$50 \mathrm{Mg} \mathrm{ha}^{-1}$, every 2 years & $2.39^{*}$ & $4.28^{* *}$ & $3.33^{* *}$ & 188 \\
\hline${ }^{*} \mathrm{LSD}_{0.05}$ & 1.08 & 1.15 & \multicolumn{2}{c}{1.02} \\
${ }^{* *} \mathrm{LSD}_{0.01}$ & 1.49 & 1.58 & \multicolumn{2}{c}{1.40} \\
${ }^{* * *} \mathrm{LSD}_{0001}$ & 2.10 & 2.17 & \multicolumn{2}{c}{1.93} \\
\hline
\end{tabular}

(1989): $\mathrm{NNI}=100 \times \mathrm{N} / 4,8 \times(\mathrm{DM})^{-0,32}$, where N: plant nitrogen content (\%), DM: dry mater production $\left(\mathrm{Mg} \mathrm{ha}^{-1}\right)$. All fodder analyses have been performed on samples taken from the first harvest cycle, based on the average values of the years 2009-2010.

The vegetation was studied using the method BraunBlanquét. For floristic data were calculated the mean abundance-dominance $(\mathrm{ADm})$. Data regarding the sharwe of economic groups, species number and Shannon Index (SI) were processed by analysis of variance.

For the production yields, statistical analyses were performed using ANOVA, applying the Least Significant Difference (LSD) test.

\section{Results and discussion}

The fertilization of mountain grasslands with organic fertilizers leads to an improvement in terms biodiversity, productivity and quality (Ansquer et al., 2009, Schellberg et al., 1999). The use of $20-50 \mathrm{Mg} \mathrm{ha}^{-1}$ manure accounted for, alongside the climatic factors, a significant yield increase, especially when applying $30-50 \mathrm{Mg} \mathrm{ha}^{-1}$. At these rates, the DM yield recorded a significant increase, compared with the control variant. Considering the average of the two years, the control variant recorded values of 1.77 $\mathrm{Mg} \mathrm{ha}^{-1}$, whereas by fertilization, it has been obtained yields of 3.29-5.53 $\mathrm{Mg} \mathrm{ha}^{-1} \mathrm{DM}$, at rates of 30-50 $\mathrm{Mg} \mathrm{ha}^{-1}$, applied on a yearly basis, and 2.86-3.33 $\mathrm{Mg} \mathrm{ha}^{-1} \mathrm{DM}$ at the same rates, applied once every 2 years, respectively.

The organic fertilization of Nardus stricta L. grasslands, with moderate rates of 20-30 $\mathrm{Mg} \mathrm{ha}^{-1}$ manure, has determined the increase in the CP (crude protein) content by $45.9 \mathrm{~g} \mathrm{~kg}^{-1} \mathrm{DM}$, compared with the unfertilized control variant. The rates of $40-50 \mathrm{Mg} \mathrm{ha}^{-1}$ diminished the percentage of dominant species and the increase of $\mathrm{CP}$ yield with $246.2-422.8 \mathrm{~kg} \mathrm{ha}^{-1}$ when manure was added once a year and 189.0-243.2 $\mathrm{kg} \mathrm{ha}^{-1}$, when manure was added every 2 years, respectively, in comparison with the control variant. The ash content increased in all fertilized soils, varying between $71.0-83.1 \mathrm{~g} \mathrm{~kg}^{-1} \mathrm{DM}$, compared to merely $61.2 \mathrm{~g} \mathrm{~kg}^{-1} \mathrm{DM}$ at the control variant. The crude fiber content (CF) was the highest at the control variant (285.3 $\left.\mathrm{g} \mathrm{kg}^{-1} \mathrm{DM}\right)$ and the lowest at the variant fertilized with $50 \mathrm{Mg} \mathrm{ha}^{-1}$, applied once every 2 years, of $228.3 \mathrm{~g} \mathrm{~kg}^{-1}$ DM (Bochi-Brum et al., 2011). Phosphorus, an important element in animal nutrition, recorded an increase from 1.4 $\mathrm{g} \mathrm{kg}^{-1} \mathrm{DM}$ at the control to $2.2 \mathrm{~g} \mathrm{~kg}^{-1} \mathrm{DM}$ with the use 50 $\mathrm{Mg} \mathrm{ha}^{-1}$ manure, applied once every 2 years (Tab. 2) (Hejcman et al., 2010). The NNI presented values comprised between 25-53, thus, indicating a deficiency in nitrogen nutrition (Agnusdei et al., 2010).

The organic fertilization on permanent grasslands has resulted in some changes in the canopy structure, both in terms of the number of species as well as in their percentage in the vegetal canopy (Duru et al., 2010; Hejcman et al., 2007; Jancovic et al., 1999; Kirkham et al., 2008; Marini et al., 2007; Oerlemans et al., 2007; Schellberg et al., 1999; Vintu et al., 2008, 2011). Thus, the number of species has increased from 18 at the control variant to 25-31 at fertilization rates, while the percentage of Nardus stricta L. species plunged from $70 \%$ at the control to $14-33 \%$ in the case of the fertilized experiments. Moreover, the legume species increased by $5-28 \%$ (Tab. 3).

Species number increased towards the control, for all fertilization variants. Shannon weaver index (SI) was compared to the control with the value between 1.07 and 2.52 .

Tab. 2. Influence of organic fertilization on yield ( $\left.\mathrm{Mg} \mathrm{ha}^{-1} \mathrm{DM}\right)$ and NNI and CP quantity $\left(\mathrm{Kg} \mathrm{ha}^{-1}\right)$ and on chemical composition of the fodder obtained from Nardus stricta grasslands ( $\left.\mathrm{g} \mathrm{kg}^{-1} \mathrm{DM}\right)$, mean 2009-2010

\begin{tabular}{|c|c|c|c|c|c|c|c|}
\hline Manure rate & $\mathrm{Mg} \mathrm{ha}^{-1} \mathrm{DM}$ & $\mathrm{CP}$ & Ash & $\mathrm{CF}$ & $P_{\text {tonal }}$ & $\mathrm{Kg} \mathrm{ha}^{-1} \mathrm{CP}$ & NNI \\
\hline Unfertilized control & 1.77 & 62.6 & 61.2 & 285.3 & 1.41 & 110.8 & 25 \\
\hline $20 \mathrm{Mg} \mathrm{ha}^{-1}$, every year & 2.48 & $88.2^{* * *}$ & 71.0 & 264.2 & $1.92^{*}$ & 218.7 & 39 \\
\hline $30 \mathrm{Mg} \mathrm{ha}^{-1}$, every year & $3.29^{* *}$ & $108.5^{* * *}$ & 83.1 & 270.4 & $2.05^{*}$ & 357.0 & 53 \\
\hline $40 \mathrm{Mg} \mathrm{ha}^{-1}$, every year & $4.17^{* * *}$ & $97.9^{* * *}$ & 78.2 & 258.1 & $2.13^{* *}$ & 408.2 & 52 \\
\hline $50 \mathrm{Mg} \mathrm{ha}^{-1}$, every year & $5.53^{* * *}$ & $96.5^{* * *}$ & 81.6 & 253.6 & $2.04^{*}$ & 533.6 & 55 \\
\hline $20 \mathrm{Mg} \mathrm{ha}^{-1}$, every 2 years & 2.60 & $82.8^{* * *}$ & 79.0 & 247.5 & $1.86^{*}$ & 215.3 & 37 \\
\hline $30 \mathrm{Mg} \mathrm{ha}^{-1}$, every 2 years & $2.86^{*}$ & $92.2^{* * *}$ & 77.5 & 241.6 & $2.17^{*}$ & 263.7 & 43 \\
\hline $40 \mathrm{Mg} \mathrm{ha}^{-1}$, every 2 years & $2.96^{*}$ & $101.3^{* * *}$ & 80.7 & 230.5 & $1.95^{*}$ & 299.8 & 48 \\
\hline $50 \mathrm{Mg} \mathrm{ha}^{-1}$, every 2 years & $3.33^{* *}$ & $106.3^{* * *}$ & 79.2 & 228.3 & $2.22^{* *}$ & 354.0 & 52 \\
\hline
\end{tabular}

$\mathrm{CP}=$ crude protein, $\mathrm{CF}=$ crude fiber, $\mathrm{P}_{\text {total }}=$ total phosphorus, $\mathrm{NNI}=$ nitrogen nutrition index; ${ }^{*}=P \leq 0.05 ;{ }^{* *}=P \leq 0.01 ;{ }^{* * *}=P \leq 0.001$ 
Tab. 3. Influence of organic fertilization on the evolution of the vegetal canopy, 2010

\begin{tabular}{|c|c|c|c|c|c|c|c|c|c|}
\hline \multirow{2}{*}{ Species } & \multicolumn{9}{|c|}{ Plant ADm ${ }^{1}$, degree $\%$} \\
\hline & $\mathrm{V}_{1}$ & $\mathrm{~V}_{2}$ & $\mathrm{~V}_{3}$ & $\mathrm{~V}_{4}$ & $\mathrm{~V}_{5}$ & $\mathrm{~V}_{6}$ & $\mathrm{~V}_{7}$ & $\mathrm{~V}_{8}$ & $\mathrm{~V}_{9}^{2}$ \\
\hline Agrostis capillaris & + & 5 & 3 & 2 & 1 & + & + & + & 5 \\
\hline Anthoxanthum odoratum & - & 4 & + & - & + & 3 & 6 & 4 & 5 \\
\hline Briza media & + & 6 & 6 & 5 & 6 & 8 & 7 & 8 & 10 \\
\hline Cynosurus cristatus & - & - & - & - & - & 3 & + & - & - \\
\hline Dactilys glomerata & - & - & - & - & 3 & - & - & - & - \\
\hline Festuca pratensis & - & + & 10 & 6 & 2 & - & - & 2 & - \\
\hline Festuca rubra & + & 1 & + & 3 & 3 & + & 5 & 5 & 3 \\
\hline Nardus stricta & 70 & 32 & 15 & 14 & 15 & 41 & 32 & 33 & 31 \\
\hline Phleum pratense & + & 7 & 2 & - & - & - & - & - & 2 \\
\hline Grasses & 70 & 55 & 36 & 30 & 30 & 55 & 50 & 52 & 56 \\
\hline Lotus corniculatus & - & 18 & 13 & 2 & 3 & 5 & 5 & 5 & + \\
\hline Trifolium pratense & + & 10 & 5 & 3 & 5 & 3 & 4 & 3 & 5 \\
\hline Trifolium repens & - & + & + & - & + & 2 & 3 & 2 & + \\
\hline Legumes & 0 & 28 & 18 & 5 & 8 & 10 & 12 & 10 & 5 \\
\hline Achillea millefolium & + & 3 & 12 & 35 & 40 & 20 & 9 & 6 & 5 \\
\hline Ajuga reptans & + & + & + & + & + & + & + & + & + \\
\hline Alchemilla xanthochlora & 6 & 2 & 6 & 2 & 6 & 3 & 6 & 3 & 6 \\
\hline Chrysanthemum leucanthemum & 2 & 3 & - & - & - & - & - & - & - \\
\hline Campanula obietina & - & + & + & + & + & + & + & 2 & 4 \\
\hline Centaurea cyanus & - & - & + & - & - & - & - & - & - \\
\hline Cerastium semidecandrum & 1 & + & + & + & + & + & 5 & 3 & + \\
\hline Cruciata glabra & 2 & 2 & 3 & + & 3 & + & + & 3 & 3 \\
\hline Fragaria vesca & - & - & + & + & + & + & + & + & + \\
\hline Hyeracium pilosella & 3 & 2 & 3 & + & - & + & - & + & + \\
\hline Hypericum maculatum & 2 & + & 1 & 3 & 2 & 2 & 4 & 6 & 6 \\
\hline Leucanthemum vulgare & - & - & + & - & - & - & - & - & + \\
\hline Luzula multiflora & - & - & - & - & - & + & + & - & - \\
\hline Lychnisflos-cuculi & - & - & + & + & + & + & - & - & - \\
\hline Prunella vulgaris & + & + & + & + & - & + & + & - & + \\
\hline Polygala amarella & - & - & - & - & - & - & + & - & - \\
\hline Polygala vulgaris & - & - & - & - & + & + & - & - & - \\
\hline Plantago lanceolata & - & - & + & + & 3 & + & + & 2 & + \\
\hline Potentila ternate & 5 & 4 & 5 & + & 4 & 5 & - & 2 & 2 \\
\hline Rumex acetosa & - & - & - & - & - & + & - & + & - \\
\hline Rumex acetosella & - & 1 & + & - & + & 1 & + & - & - \\
\hline Ranunculus acer & 1 & - & + & 2 & 2 & 1 & + & 2 & + \\
\hline Taraxacum officinale & 2 & 0 & 2 & + & + & 3 & 4 & 4 & - \\
\hline Thymus pulegioides & 2 & - & 2 & - & - & + & + & + & - \\
\hline Tragopogon pratensis & - & + & - & - & - & + & + & - & + \\
\hline Veronica chamaedrys & 1 & + & 12 & + & - & - & 10 & 5 & 1 \\
\hline Veronica officinalis & 1 & - & - & 23 & 2 & - & - & - & 7 \\
\hline Viola tricolor & 2 & + & + & + & - & + & + & + & 5 \\
\hline Forbs & 30 & 17 & 46 & 65 & 62 & 35 & 38 & 38 & 39 \\
\hline Number of species & 18 & 25 & 30 & 25 & 26 & 31 & 28 & 26 & 27 \\
\hline Shannon Index (SI) & 1.07 & $2.27^{*}$ & $2.52^{*}$ & 1.93 & $2.15^{*}$ & 1.96 & $2.28^{*}$ & $2.50^{*}$ & $2.41^{*}$ \\
\hline
\end{tabular}

${ }^{1} \mathrm{ADm}$-mean abundance-dominance; ${ }^{2} \mathrm{~V}_{1}$ is control, $\mathrm{V}_{2}-\mathrm{V}_{9}$ are the manure rates applied; ${ }^{*}=P \leq 0.05,{ }^{* *}=P \leq 0.1,{ }^{* * *}=P \leq 0.001$

\section{Conclusions}

The fertilization of Nardus stricta grasslands with 20-50 $\mathrm{Mg} \mathrm{ha}^{-1}$ manure influenced the yield increase by $40-212 \%$ and brought along important changes in the chemical composition of fodder, improving its quality significantly, by increasing the $\mathrm{CP}$ content from $62.6 \mathrm{~g} \mathrm{~kg}^{-1} \mathrm{DM}$ (control) to 108.5 (30 Mg ha ${ }^{-1}$ manure, applied once every 2 years); the total phosphorus from 1.41 to $2.22 \mathrm{~g} \mathrm{~kg}^{-1} \mathrm{DM}$ and ash from 61.2 to $83.1 \mathrm{~g} \mathrm{~kg}^{-1}$, and by diminishing the 
CF content from 285.3 to $228.3 \mathrm{~g} \mathrm{~kg}^{-1} \mathrm{DM}$, thus increasing fodder digestibility.

The application of $20-50 \mathrm{Mg} \mathrm{ha}^{-1}$ manure determined important changes in the flower composition as well, by lowering the percentage of Nardus stricta species from $70 \%$ to $14-33 \%$ and increasing the percentage of legumes ( $L o$ tus corniculatus, Trifolium pratense and Trifolium repens) and forbs.

\section{References}

Aarssen LW (1997). High productivity grassland ecosystems effected by species diversity or productive species? Oikos 80(1):183-184.

Agnusdei MG, Assuero SG, Lattanzi FA, Marino MA (2010). Critical $\mathrm{N}$ concentration can vary with growth conditions in forage grasses: implications for plant $\mathrm{N}$ status assessment ant $\mathrm{N}$ deficiency diagnosis. Nutr Cycling Agroeco 88(2):215230.

Ansquer P, Khaled RAH, Cruz P, Theau JP, Therond O, Duru M (2009). Characterizing and predicting plant phenology in species-rich grasslands. Grass Forage Sci 64(1):57-70.

Bakker JP, Elzinga JA, de Vries Y (2002). Effects of long-term cutting in a grassland system: perspectives for restoration of plant communities on nitrient-poor soils. Appl Veget Sci 5(1):107-120.

Basnou C, Pino J, Smilauer P (2009). Effect of grazing on grasslands in the Westwrn Romanian Carpathians depends on the bedrock type. Preslia 81(2):91-104.

Belanger G, Tremblay GF, Mongrain D (2008). Yield and nutritive value of the spring growth of an ageing timothy sward. Can J Plant Sci 88(3):457-464.

Bochi-Brum O, Garcia R, Bodas R, Calleja A, Andres S, Lopez $S$ (2011). Nutritive value of herbage from mountain hay meadow managed under traditional and intensive harvest systems as affected by nitrogen fertilisation and time of cutting. Animal Prod Sci 51(6):549-556.

Bullock JM, Pywell RF, Walker KJ (2007). Long-term enhancement of agricultural production by restoration of biodiversity. J App Ecol 44(1):6-12.

Dodd MB, Barker DJ, ME Wedderburn (2004). Plant diversity effects on herbage production and compositional changes in New Zealand hill country pastures. Grass Forage Sci 59(1):29-40.

Duru M, Cruz P, Theau JP (2010). A simplifies for characteristing agronomic services provided by species-rich grasslands. Crop Pasture Sci 61(5):420-433.

Gaisler J, Hejcman M, Pavlu V (2004). Effect of different mulching and cutting regimes on the vegetation of upland meadow. Plant Soil Environ 50(7):324-331.

Hejcman M, Szakova J, Schellberg J, Tlustos P (2010). The Rengen Grassland Experiment: relatioship between soil and biomass chemical properties, amount of elements applied, and their uptake. Plant Soil 333(1-2):163-179.
Hejcman M, Klaudisova M, SchellbergJ, Honsova D (2007). The Rengen Grassland Experiment: Plant species composition after 64 years of fertilizer application. Agricult Ecosyst Environ 122(2):259-266.

Jancovic J, Holubek R, Santrucek J (1999). Botanical and production changes of permanent grassland after cessation of mineral fertilization. Rostlinna Vyroba 45(1):23-27.

Janssens F, Peeters A, Tallowin JRB, Bakker JP, Bekker RM, Fillat F, Oomes MJM (1998). Relationship between soil chemical factors and grassland diversity. Plant Soil 202(1):69-78.

Klavina D, Adamovics A, Straupe I (2001). Botanical composition and productivity of meadows in Tervete Nature Park. Conference on sustainable agriculture in Baltic States, 54-56 p.

Kirkham FW, Tallowin JRB, Sanderson RA, Bhogal A, Chambers BJ, Stevens DP (2008). The impact of organic and inorganic fertilizers and lime on the species-richness and lant functional characteristics of hay meadow communities. Biol Conserv 141(5):1411-1427.

Magyar EI, Buchgraber K, Warner D (2008). Influence of soil and fertilization on the plant composition in a permanent grassland. Cereal Res Commun 36:1979-1982.

Marini L, Scotton M, Klimek S, Isselstein J, Pericle A (2007). Effect of local factors on plant species richness and composition of Alpine meadows. Agricult Ecosyst Environ 119(3-4):281-288.

Oerlemans J, von Boberfeld WO, Wolf D (2007). Impact of long-term nutrient supply on plant species diversity in grassland: an experimental approach on conventionally used pastures. J Appl Bot Food Quality 31(2):151-157.

Potsch EM (1998). About the influence of the fertilizing intensity on the $\mathrm{N}$-cycle of alpine grassland. Bodenkultur 49(1):19-27.

Schellberg J, Moseler BM, Kuhbauch W, Randemacher IF (1999). Long-term effects of fertilizer on soil nutrient concentration, Yield, forage quality anf floristic composition of a hay meadow in the Eifel mountains, Germany. Grass Forage Sci 54(3):195-207.

Tilman D, Wedin D, Knops J (1996). Productivity and sustainability influenced by biodiversity in grassland ecosystems. Nature 379(6567):718-720.

Vintu V, Samuil C, Sarbu C, Saghin Gh, Iacob T (2008). The influence of grassland management on biodiversity in mountainous region of NE Romania. Grassland Sci Eur 13:183-185.

Vintu V, Samuil C, Rotar I, Moisuc Al, Razec I (2011). Influence of the Management on the Phytocoenotic Biodiversity of Some Representative Grasslands Types from Romania. Not Bot Horti Agrobo 39:119-125. 